ANUARIO DE Estudios MEDIEVALES

$46 / 1$, enero-junio de 2016 , pp. 393-415

ISSN 0066-5061

doi:10.3989/aem.2016.46.1.12

\title{
THE QUEEN, THE PRINCE, AND THE IDEOLOGUE: ALONSO ORTIZ'S NOTIONS OF QUEENSHIP AT THE COURT OF THE CATHOLIC KINGS
}

\author{
LA REINA, EL PRÍNCIPE Y EL IDEÓLOGO: \\ ALONSO ORTIZ Y SUS NOCIONES DE REGINALIDAD \\ EN LA CORTE DE LOS REYES CATÓLICOS
}

\author{
NÚRIA SILLERAS-FERNÁNDEZ \\ University of Colorado at Boulder
}

\begin{abstract}
In the court of the Catholic Monarchs (r. 1474-1516), Isabel I of Castile and Fernando II of Aragon, that of a ruling queen, humanists constructed theories of what it meant to be a ruler. Alonso Ortiz, one of the humanists attached to their court, composed the Latin text, Liber de educatione Johannis Serenissimi Principis et primogeniti regum potentissimorum Castelle Aragonum et Siciliae Ferdinandi et Helisabet inclyta prosapia coniugum clarissimorum, a book that reflects an idealized and disempowered humanist vision of elite women that contrasts with the agency they wielded in historical fact.
\end{abstract}

Keywords: queenship; medieval monarchy; humanism; discourse; gender; mirrors of princess; Alonso Ortiz; Isabel I of Castile; Catholic Kings; Prince Juan; medieval Iberia.

\begin{abstract}
Resumen: En la corte de los Reyes Católicos (1474-1516), Isabel I de Castilla y Fernando II de Aragón, una corte en la que una reina gobernaba, los humanistas construyeron teorías sobre lo que significaba ser un gobernante. Alonso Ortiz, un humanista de su corte, compuso el texto latino: Liber de educatione Johannis Serenissimi Principis et primogeniti regum potentissimorum Castelle Aragonum et Siciliae Ferdinandi et Helisabet inclyta prosapia coniugum clarissimorum, libro que refleja una visión idealizada y despojada de poder de las mujeres de la élite, hecho este que contrasta con la capacidad de actuación que éstas tuvieron según la evidencia histórica.
\end{abstract}

Palabras clave: reginalidad; monarquía medieval; humanismo; discurso; género; espejos de príncipes; Alonso Ortiz; Isabel I de Castilla; Reyes Católicos; príncipe Juan; Península Ibérica medieval.

\section{SUMMARY}

1. Introduction.- 2. Alonso Ortiz and his writings.- 3. A mirror for a prince, a mirror for his mother.- 4 . Conclusions.- 5. Bibliography. 


\section{INTRODUCTION}

Customarily scholars have considered the long reign of the Catholic Kings (r. 1474-1516) a decisive moment in the history of Spain ${ }^{1}$. They were associated with a series of policies and events whose repercussions can only be fully appreciated over the longue durée, including the dynastic union of the crowns of Castile and Aragon, the creation of the Spanish Inquisition, the expulsion of the Jews, the conquest of Granada, the last Muslim kingdom in the Iberian Peninsula (and, subsequently, the forced conversion of its Muslim inhabitants), and last but not least, the voyages of Christopher Columbus and the beginning of the colonization and exploitation of the Americas. Their policies not only shaped Iberia for the centuries to come, but had further and complex ramifications in world history. In addition to all of this, their itinerant court has traditionally been credited as a space of cultural innovation, debate, and exchange, and a locus of Humanism.

The fact that Isabel I was queen of Castile in her own right, and that she married another king in his own right, Fernando II (or Ferran) of Aragon, was also anomalous. Their particular union and the manner in which they shared power and authority, as expressed in their famous motto tanto monta, monta tanto, Isabel como Fernando (Isabel and Fernando, they amount to the same), carried with it a reconceptualization of the meaning of monarchical power and the allocation of authority ${ }^{2}$. Even though in practice the medieval monarchy was collaborative or corporate -in the sense that the partnership and sharing of responsibilities of the king, at least with his wife and children (and particularly the heir-apparent), was implicit- in theory the monarch was

\footnotetext{
${ }^{1}$ Isabel was the daughter of Juan II of Castile (r. 1406-1454), and the half-sister of Enrique IV (r. 1454-1474), whose only child, Juana "la Beltraneja," was widely regarded as the product of an adulterous liaison of his wife and the royal favorite, Beltrán de la Cueva. In 1469, Isabel married her cousin, Fernando (Ferran) II of Aragon, and together they ascended the throne of Castile in 1474, and that of Aragon in 1479. Their path to the throne was not easy, and the consolidation of their position was only possible after winning a civil war against the deceased king's heir, Juana and her husband, Afonso V of Portugal (r. 1447-1481). On December 19, 1496, Pope Alexander VI (1492-1503) bestowed on them the honorific title "The Catholic Kings" in his bull. For an overview see Suárez Fernández 1989.

${ }^{2}$ Regarding the meaning of this motto and other symbols related with the Catholic Monarchs, see Weissberger 2004, pp. 48-52; Guardiola-Griffiths 2011, p. 16; González Iglesias 1994, López Poza 2012, p. 8. In a letter written to Ascanio Viconti (1 August 1488), the humanist, Pedro Martínez de Anglería, qualified the particular sharing of government between Isabel and Fernando in the following terms: "En todos ellos [in the crown of Castile] se hace cuanto ella [queen Isabel] ordena; pero de tal manera manda, que siempre parezca hacerlo de acuerdo con su marido (...) En cambio, los reinos que por derecho hereditario vinieron a manos del Rey (...) son gobernados por él solo", Nieto Soria 2006, p. 48.
} 
seen as the sole ruler wielding authority ${ }^{3}$. Thus, the nature of the reign of the Catholic Kings challenges common expectations and presumptions regarding the nature of the medieval monarchy and offers further proof that rulership and kingship were not synonymous, and that, while power may have usually been centered on a monarch, it could be shared by other members of his family -most clearly, the queen, and the heir-.

In my view, as historians we should not conceive of politics and government narrowly. For instance, we need to study queenship from an array of perspectives, and look for networks of religious, cultural, and familial patronage, because in the Middle Ages "political" activities cannot be sectioned off from the wider activities of the royal and queenly court ${ }^{4}$. In other words, for women, politics, and statecraft go far beyond a woman's capacity as a queen in her own right, or a lieutenant, or regent. All queens were political and exercised power in one way or another, whether or not they had an "official" status ${ }^{5}$. One of the problems in understanding medieval rulership and queenship is that sometimes scholars give too much credit to texts, such as mirrors of princes (and of princesses), that tended to be tailored to a specific ruler, and intended to give him or her advice regarding how to rule (whether solicited or unsolicited). Those texts are certainly relevant to understanding medieval politics, but they reflect a theoretical model of government and behavior that did not necessarily coincide with historical reality, and tend to offer a model of agency for women that is very restricted ${ }^{6}$. As queenship studies have shown over the last twenty years or so, the medieval monarchy was more fluid than rigid, and rather than merely generalizing about the role of women, it is key to study events in their very particular context and circumstances ${ }^{7}$. In this article I will take this as a starting point, in order to explore the relationship between queenship, government, and ideology by briefly analyzing a book of advice or mirror

${ }^{3}$ For a discussion of the role of the queen in the medieval monarchy in general, and in Iberia more specifically see Wolf 1998; Earenfight 2007, pp. 1-10; 2013; Silleras-Fernández 2003; 2005-2006; 2008, pp. 5-7; 2015c, p. 266; Pelaz 2013; Echevarría 2002; Shadis 2009; Bianchini 2012, pp. 5-8; Woodacre 2013.

${ }^{4}$ See Silleras-Fernández 2008.

${ }^{5}$ A useful definition of power is that of Moisés Naim: "Power is the ability to direct or prevent the current or future actions of other groups and individuals. Or, put differently, power is what we exercise over others that leads them to behave in ways they would not otherwise have behaved", Naim 2013.

${ }^{6}$ For a comparative study that deals with a similar problem (the gap between the theoretical model portrayed in mirrors of princes and actual rulership, in sixteenth century Portugal), see Silleras-Fernández 2015a. For an overview on the literature of the Reign of the Catholic Kings, see Gómez Redondo 2012, and for a specific discussion on Ortiz, see ibidem, vol. I, pp. 839-848.

${ }^{7}$ For a general overview see Earenfight 2013. 
of princes written for Prince Juan under the auspices of Isabel I of Castile (r. 1474-1504) .

In the following pages I will discuss how in the particular context of Isabel and Fernando's royal court -one that had a ruling queen- humanists constructed theories of what it meant to be a ruler. For the sake of brevity, I will focus on a case study that in my view exemplifies the problems this presented for them ${ }^{9}$. Thus, I will explore the debate regarding womanhood, queenship, and education that took place during the reign of the Catholic Kings, by analyzing the writings of Alonso Ortiz (c. 1455-1507), one of the intellectuals of their entourage who strove through his literary production to establish a relationship of patronage with the royal family. Concretely, I will discuss one of his texts, the Liber de educatione Johannis Serenissimi Principis et primogeniti regum potentissimorum Castelle Aragonum et Siciliae Ferdinandi et Helisabet inclyta prosapia coniugum clarissimorum (The Book of the Education of John, the Most Serene Prince and First-Born of the Most Powerful King of Castile, Aragon and Sicily, the Renowned Couple, Isabel of Illustrious Lineage and Ferdinand $)^{10}$. I contend that in this book -a work that Ortiz ostensibly wrote for Prince Juan, Isabel and Fernando's heir to the thrones of Castile and Aragon- the author's goal was in fact not only to instruct the young prince, but also his mother, Isabel, as to what her role in society should be. Therefore, the text can serve as an example to help us understand expectations regarding queenship, kingship, and education, and how they related to humanistic discourse in an age that marked the transition from the Middle Ages to the Early Modern period.

\section{ALONSO ORTIZ AND HIS WRITINGS}

Today, Alonso Ortiz is a rather obscure historical personality, but during his lifetime he was a well-respected humanist, and served for a time as a royal chaplain at the court of Isabel and Fernando -a position he combined

\footnotetext{
${ }^{8}$ There are many studies on the Catholic Kings, the most relevant ones for my argument in this article are Weissberger's groundbreaking book, Isabel Rules, Weissberger 2004; GuardiolaGriffiths 2011; Fernández de Córdova 2002, 2004; Ruiz 2004. Among Isabel's many biographical studies, see Azcona 1993; Liss 2004; Rubin 1991; Val Valdivieso 2004.

${ }^{9}$ This article is part of a broader project on humanistic discourse, politics, and gender in which I will analyze the ideological bases of queenship (and to a lesser extend kingship), and how they relate to the actual practice of it, the historical evidence.

${ }^{10}$ This book is preserved in manuscript form at the Universidad de Salamanca (Ms. 368) bound together with another one titled Consolatoria super obitu inclyti principis Johannis. The original text of the Liber educatione remains unedited, but Giovanni Maria Bertini edited a version of the book translated to Spanish. See Ortiz 1983, p. 1.
} 
with his clerical obligations at the Cathedral of Toledo and with teaching-. Unfortunately, not too many details regarding his life survive ${ }^{11}$. We know, for example, that he lived in Rome from 1473-1478, that he received his doctorate in Civil and Canonical Law from the University of Salamanca, that he and his brother, Francisco, were clergymen at the Cathedral of Toledo, and that both were accused of sodomy and of disobeying Archbishop Cisneros -as Antonio García Vallalpando's visitation record of 1499 shows $^{12}-$. No wonder why, as we will see, he dedicated some of his works to archbishops. On his death in 1507 he bequeathed his rich library of over six hundred volumes to his alma mater $^{13}$. He was buried, along with his mother, at the Cathedral of Toledo, where he had been a canon ${ }^{14}$. In 1494-1495 the German traveler Hieronymus Münzer (c. 1437-1508) visited the Iberian Peninsula, and in his travelogue, known as the Itinerarium Hispanicum Hieronymi Monetarii, he included a description of Ortiz:

La sacristía (de la catedral de Toledo) es quizá mayor que la de Guadalupe y acaso más primorosa. Entré a verla con el claro varón Alonso Ortiz, canónigo de la Catedral, jurisconsulto y consumado poeta, cuyo saber se reflejaba bien en sus palabras ${ }^{15}$.

In my view, Ortiz was a writer who through his works attempted to influence, justify, and glorify the policies of the Catholic Kings -monarchs who he was courting actively as patrons, especially Isabel. In a text that he wrote for them in 1492 -a time when the monarchs were in Barcelona, where they granted an audience to Columbus- Ortiz, with characteristic flattery, claimed that there could not exist people that were so "barbarous" as to not be aware of all the great things the royal couple had achieved, not even in the "Indies" service of monarchical power; moreover, he was a writer who had his own particular agenda, relating to issues as diverse as the position of humanists at the royal court and in education, what the role of women in society ought to be, and the advantages of the Inquisition. Regarding the latter, he was also the protagonist of a very intense intellectual dispute that took place in Castile and Aragon regarding the forced conversion of Jews and Muslims and the role of

\footnotetext{
${ }^{11}$ García Castillo 2012, pp. 37-39.

${ }^{12}$ Alonso Ortiz is listed as "doctor" and Francisco as "licenciado". Lop 2005, pp. 639, 652, 659, 668; Lop 2002, pp. 381, 384, 464, 750, 804-806; García Oro 1971, pp. 294-298.

${ }^{13}$ Ortiz 1983, p. 1. Regarding Alonso Ortiz's library see Sanz 1997a, 2000, pp. 19-21.

${ }^{14}$ Ibidem, p. 18; Lop 2013, p. 358.

${ }^{15}$ Ortiz 1983, p. 8; Münzer 1924, p. 248.

${ }^{16}$ Fanego 2001, pp. 98-99.
} 
the Inquisition in society. This was an institution that was deeply controversial even in its own time, but one that he considered positive, encouraging the monarchs to utilize and support it. Ortiz was, thus, a participant in powerful cultural processes at the juncture of the Medieval and the Modern eras, processes that were key to shaping concepts of nationalism, identity, gender, religion, and the nature of institutional power that are still current today.

When a medieval author like Alonso Ortiz dedicated a book to someone in particular, which was a common custom in this period, there was always a reason behind it, and typically it reflected an aspiration on the part of the writer of strengthening ties to the recipient, and ultimately to benefit from his or her network of influence, patronage, and protection ${ }^{17}$. Those with positions close to the queen, the king, or the heir could even hope to directly influence the politics and trends of the time. Thus, in analyzing such a work it is important to historicize the relationship between the author and the person to whom the work was dedicated, as well as the audience the book was aimed at. Ortiz's case is particularly relevant because he dedicated most of his books to different members of the royal family, and to other important religious figures of his time, like the archbishops Carrillo, Mendoza, and Cisneros. For instance, he not only wrote the speculum principium that I will be discussing, but also five other treatises for the royal family, all either in Castilian or Latin, some of which he translated with the goal of finding a broader readership. These include: Tratado de la herida del rey (Treaty of the Wound of the King), Tratado consolatorio a la princesa de Portugal (Treaty of Consolation for the Princess of Portugal), Oración a los reyes en latín y en romance (Prayer to the Kings in the Latin and Romance Language), Dos cartas mensajeras a los reyes (Two Missive Letters to the Monarchs), and Tratado contra la carta del protonotario de Lucena (Treaty of the Letter against the Notary Lucena). The first of these texts was intended for King Fernando, and the second one for Isabel, Princess of Portugal (the Catholic Monarchs' eldest daughter). The prayer and the two letters were composed for both monarchs, while the letter against Lucena aimed to bolster royal policies in support of the Inquisition ${ }^{18}$. Ortiz's five treatises first circulated in manuscript form and then they were published in Seville in 1493 as a single volume ${ }^{19}$. Finally, he is the author of a book intended as a consolation for Prince Juan's death, Tratado del

\footnotetext{
${ }^{17}$ As Roger Chartier has underlined "The practice [of dedications] was central to the economy of patronage, which obligated the dedicatee to accord protection, employment, or remuneration in exchange for the book dedicated, offered, and accepted", Chartier 1995, p. 41.

${ }^{18}$ Azcona 1993, pp. 513-515.

${ }^{19}$ See a copy of Ortiz's incunabula published in Seville in 1493 at the library of the Royal Monastery of El Escorial (Inc. 23-V-11) titled Los tratados del Doctor Alonso Ortiz (The treatises of Dr. Alonso Ortiz).
} 
Fallesçimiento del Muy Inclito Señor Don Juan (Treaty on the Death of the Renown Lord Juan), as well as other Latin treatises and additional projects, such as the correction and edition of important religious texts like the Mozarab Missal and Breviary, and translations of devotional books ${ }^{20}$.

In other words, Ortiz mostly wrote books with the royal family in mind, and these were perfectly tailored to what he perceived as their needs at the particular moment he wrote. These writings ended up enjoying a much broader audience, either in the royal court, or a general readership (thanks to the printing press), but this is of secondary importance in his case. The fact that he was also interested in providing counsel to other members of the royal family shows that they were a group formed by a complex set of individuals with inter-related vectors of power, influence, and authority. It was important for a courtier to have contact with all of them, and not only the ruling monarchs.

\section{A MIRROR FOR A PRINCE, A MIRROR FOR HIS MOTHER}

As a genre, mirrors of princes provide a particularly interesting view of contemporary expectations regarding political power, the monarchy, and education ${ }^{21}$. But again, "expectations" and historical reality are two different things. Mirrors were written by clergymen or laymen who accustomed to either have some sort of position at the royal court or who were seeking one. These works tended to be moralistic in tone and, simultaneously, very pragmatic and shaped to the presumed needs of the particular ruler for whom they were written,

\footnotetext{
${ }^{20}$ Ortiz completed the revision of the Misal Toledano, first upon the request of Archbishop Mendoza. When that edition did not circulate, due to its many errors, Cardinal Cisneros commissioned a new one from him. This was published in Toledo in 1499. Cisneros also put him in charge of the revision and edition of the Mozarab Missal and Breviary, published in Toledo in 1500 and 1502, respectively, Pérez 2014, p. 223. Thus, Ortiz collaborated with two key figures of his time. Apart from constituting a very interesting example of an author who translated his own works from Latin to Castilian (like his Consolatoria super obitu principis Johannis or his Ad Illustrisimos Fernandum et Helisabeth Hispaniarum regem et reginam potentissimos Alfonsi Ortiz doctoris oratio ), Ortiz also undertook other translations, Fanego 2001 and 2003; González, Baños, Saquero 2005. For instance, queen Isabel asked him for a translation of the Arbor vitae crucifixae Jhesu Christi by Ubertino da Casale, which he dedicated to her, Sanz 1997b. Likewise, he is the translator of the first Spanish printed edition of the Meditaciones muy devotas del bienaventurado Sant Anselmo (Toledo: 1504), which he offered to Diego López de Pachecho, Marquis of Villena, Sanz 1997b, pp. 188-189, 191. He also wrote De lamentatione generis humani, a sort of history of humanity, and also dedicated to queen Isabel. Other works include De regimine regnis, and the Liber dialogorum (for more on these, see this article's next section). He is also the author of the hagiographies of Ildefonso and Leocadia, two saints from Toledo. See García Castillo 2012, pp. 41-42; González Ruiz 1992, and for a complete list of his works, Sanz 2000, pp. 17-21, 41-45; Alcalá, Sanz 1999, pp. 57-59.

${ }^{21}$ For a brief overview of Castilian mirrors see Nogales 2006; Nieto Soria 1999.
} 
translated, or adapted. The idea was that the text would serve as a mirror, as it were, in which the ruler could contemplate himself, and by improving himself, then become a model (or a "mirror") for his subjects. Because of the nature of the royal family in general, and the particular circumstances of the Catholic Monarchs, I believe the speculum principium that Ortiz dedicated to Prince Juan was, in reality, aimed just as much at Isabel, the presumed queen-mother. Hence, it is a book that says as much about queenship as kingship. Thus, his speculum sheds light onto the contemporary conception of monarchy (at least among humanist court intellectuals), as to what the proper education for a prince ought to be, and the roles of the king and the queen. It is, therefore, a text that reflects the multiple character of the medieval monarchy.

Ortiz's Mirror was written in Latin and as its long and rather descriptive title -Liber de educatione Johannis Serenissimi Principis et primogeniti regum potentissimorum Castelle Aragonum et Siciliae Ferdinandi et Helisabet inclyta prosapia coniugum clarissimorum (from now on Liber de educatione) - states, it was dedicated to Prince Juan. He was Isabel and Fernando's second born child and their only son, and thus the presumed heir. They also had four daughters: Isabel, Juana, Maria, and Catalina, and even though women were allowed to rule in Castile (in contrast to Aragon, where they were effectively excluded from doing so), men were given preference. Therefore, in 1478, Juan's birth, nine years after his parents' marriage, was both long anticipated and happily celebrated. This can be seen, for example, in a letter that Fernando del Pulgar, secretary and chronicler of the monarchs, sent Doctor Talavera shortly after the prince's birth in Seville, in June 30, 1478. Here, the chronicler waxes messianic:

Señor: del nacimiento del príncipe, con salud de la reina, ovimos acá muy gran placer. Claramente vemos sernos dado por especial don de Dios pues al fin de tan larga esperança le plugo dárnosle. Pagado ha la reina este reino la deuda de sucesión viril que era obligada de le dar. Quanto yo, por fe tengo que ha de ser el más bienaventurado príncipe de mundo, porque estos que nascen desseados, son amigos de Dios, como fue Isaque, Samuel e Sant Juan, e todos aquellos de quien la sacra scriptura faze mención que ovieron nacimientos como éste muy deasados ${ }^{22}$.

For Pulgar, the most important role of any queen, even one ruling in her own right, was, first and foremost, reproductive. Her calling was to secure a male heir who would ensure the continuity of the dynasty and, therefore, the peace and prosperity of the kingdoms. The fact that Isabel was a female ruler,

${ }^{22}$ See Pérez Priego's introduction to Pulgar 2007, p. 14; 1953. 
or that, as the historical record shows, in the Middle Ages there were many powerful childless queens, did not impress him $^{23}$. Pulgar stated very clearly that Isabel had paid her "debt" in this respect (la deuda de sucesión viril que era obligada de le dar). Of course, after his birth, the heir she produced had to be properly educated for the role ahead of him as heir of Castile and Aragon. His sisters also had to be taught correctly, even though it was not imagined that they would rule. Traditionally, many queens took care of their children's education, and Isabel's account books show that she planned the education of all of them carefully ${ }^{24}$.

Ortiz's aim was to contribute to this education, and particularly to that of the future king of Castile and Aragon. His rather long and exhaustive Liber de educatione is divided in two parts of twenty-one and sixty-one chapters, respectively; the first one focuses more on general Christian and philosophical principles, while the second one concentrates in education per $s e^{25}$. He wrote the treatise in Latin because he was promoting the humanist method, and he considered it the best and most appropriate language. This resonated with the culture of the royal court; it is well known that Isabel took the time to improve her Latin as an adult, and that Prince Juan, like his sisters (Isabel, Juana, María, and Catalina), knew Latin very well. Isabel's children received a top-rate education in the latest humanist fashion. The renowned valencian humanist, Joan Lluís Vives, praised the infantas' facility with Latin, in his De institutione feminae christianae (Instruction of a Christian Woman, 1523, revised in 1538):

${ }^{23}$ A very obvious example of this dynamic in the Iberian Peninsula is that of Maria de Castilla who did not have any children with her husband, the king of the Crown of Aragon Alfons the Magnanimous (1416-1458), and who nevertheless governed as her husband's lieutenant general of the whole Crown of Aragon from 1420-1423 and as lieutenant of Catalonia from 1432-58 while he settled in the kingdom of Naples. See Earenfight's study on Maria de Castilla, Earenfight 2010, pp. 41-101.

${ }^{24}$ Isabel took charge of her children's education, as is reflected in her account books. See Torre, Alsina 1955, vol. I, ff. 59v (for example: "Al doctor fray Andrés, maestro de latyn, 4.130 mrs."), 65-2v, 110v, 124v, 132-2 (for example: in 1487 and to "support himself" Sancho de Castilla, Prince's Juan "ayo" received 200.000 mrs., Diego de Deça, the Prince's teacher 100.000 mrs., Pedro de Henpudia, Princess Isabel's teacher, $50.000 \mathrm{mrs}$. and Andrés de Miranda, Princess Juana's teacher 50.000 mrs. Those who taught the princesses made half the money, 140, 155v, 170, 172, 214-2, 232-2; II, ff. 69v, 81-2v, 100, 114-2v; 124; 139-2v); Muñoz 1989, p. 428. The education of royal children also figured in Alfonso X's Siete Partidas. See Alfonso X 1807, vol. II, title 7, law 3, p. 45. On the other hand, we know very little about what type of education queen Isabel received as a child, or who taught her, in part because she lived in Arévalo, rather than at the royal court. See Salvador 2003, pp. 171-177; Segura Graiño 2007, pp. 330-332. For the role of education at her royal court see Val Valdivieso 2006; Gil 2004, pp. 1056-1062.

${ }^{25}$ See a detailed explanation of the content of the mirror in García Castillo 2012, pp. 45-46. 
People in various parts of the country tell me in words of praise and admiration that Queen Juana, wife of Philip and mother of our Emperor Charles, answered in Latin to the Latin ex tempore speeches that are customarily delivered in every town in the presence of new princes. The English say the same of their queen Catherine, sister of Juana. All say the same of the other two sisters, who met their death in Portugal ${ }^{26}$.

Ortiz's speculum is rather original ${ }^{27}$. It is constructed as a humanist dialogue in emulation of the Classics, in which two characters converse -although not so much about government and politics, as other specula do, but rather, about philosophy and religion, and more concretely, about the virtues and how to discipline the passions-. As Seneca is said to have put it: No existe virtud sin trabajo ${ }^{28}$. Ortiz's notion of virtue comes from Aristotle as is defined as the habit of choosing (hábito de escoger) and finding the golden mean (el punto mediano entre el exceso y el defecto ${ }^{29}$. Virtue is therefore, and like gender, performative ${ }^{30}$. The two characters in the dialogue are a queen, who is simply referred to as The Queen (La Reina) and who represents Isabel the Catholic, and a Cardinal, who (judging by the chronology) is most likely meant to be Pedro González de Mendoza -the famous Cardinal Mendoza (14281495)-. The son of a renowned poet, Iñigo López de Mendoza, Marquis of Santillana, and well-known for his own erudition, Cardinal Mendoza pursued an ecclesiastical career that culminated in his appointment as Archbishop of Toledo -the Primate of Spain- in 1482. We do not know for certain the date when Ortiz wrote the Liber educatione but it must have been prior to 1497, the year in which Prince Juan unexpectedly died at age nineteen, and before 1495, when Cardinal Mendoza died. Within this range, an earlier date is more likely due to the urgency in providing for the prince. The text states that Juan was an adolescent at the time, so it was likely written in the period of 1490 to 1495 , a time when Isabel was over forty years old -a mature woman who had proven herself as a successful queen ${ }^{31}$.

By choosing these two characters as interlocutors in his fictional debate, Ortiz simultaneously paid tribute to two important political figures, who knew each other well, and he did it in such a way as to court the good will

\footnotetext{
${ }^{26}$ Vives 2000,pp. 69-70.

${ }^{27}$ Comparable texts, or even models that could have influenced Ortiz were Rodrigo Sánchez de Arévalo's De arte, disciplina et modo aliendi et erudendi pueros et iuvenes and Vergel de príncipes, the latter dedicated to Enrique IV, Rábade 2007.

${ }^{28}$ Ortiz 1983, p. 170.

${ }^{29}$ Ibidem, pp. 190-191.

${ }^{30}$ See note 45 .

${ }^{31}$ García Castillo 2012, p. 46.
} 
of the future king as well. This was indeed the second time that Ortiz chose Isabel and Mendoza as protagonist of one of his dialogues. He had already done so years earlier in his Dialoguis regimini regni [seu potius de Regni et Regis institutione] inter Reginam Elizabeth et Cardinalem Mendonza, in which the cardinal explained and reassured the queen of her rightful claim to the Castilian throne ${ }^{32}$. Another comparable text, written earlier, is his Liber dialogorum, that presents a conversation between Alfonso Carrillo, Archbishop of Toledo (1446-1482), to whom the book is dedicated, and other characters, such as Wisdom, Plato, and other philosophers ${ }^{33}$. Ortiz was obviously putting his erudition at the service not only of the queen, but also of the archbishops -acting as their ventriloquist, to achieve his own ends-.

The role the characters play in the Liber educatione is also quite particular. The Cardinal is presented as a source of authority in all matters, and the perfect guide for the Queen in the difficult task of educating the future king. He appears as a very wise man, knowledgeable of Christian theology and the classics alike, and he cites these authorities constantly, dropping names such as the Pythagoreans, Plato, Aristotle, Quintilian, and other $^{34}$. In this respect, Ortiz was not only a forerunner of Humanism -of what some scholars would further qualify as "Christian Humanism"- but he was also promoting the model of the well-instructed clergyman as the perfect humanist (as both Mendoza and himself epitomized, in his mind) ${ }^{35}$. This in a time in which most of those who would be described as humanists were in fact lay men with little or no connection to the Church, even at the court of the Catholic Kings -Peninsular intellectuals like Antonio de Nebrija, and Beatriz Galindo La Latina, and Italians, like Lucio Marineo Siculo (1460$1533){ }^{36}$. There were certainly many important and knowledgeable religious figures by Isabel's side, such as her confessors, Hernando de Talavera and Francisco Jiménez de Cisneros (better known as Cardinal Cisneros); however, to Ortiz's regret, the cultural monopoly of the Church, was about to become only a memory.

${ }^{32}$ The Dialoguis regimini regni remains unedited (Biblioteca Universitaria de Salamanca: Ms. 369). See Hernando 2007, p. 356; Salvador 2006, vol. III. 1. Prosa; Azcona 2007, pp. 50-52, 329-332.

${ }^{33}$ The Liber dialogorum remains unedited. The manuscript is preserved at the Cathedral of Burgo de Osma, Ms. 40; Round 1993, p. 187.

${ }^{34}$ Another, more famous humanist, Erasmus, composed his De pueris instituendis ("On Education for Children") around 1509, just a few years after Ortiz wrote his mirror (although it was only published twenty years later). Erasmus, like Ortiz before him, advocated for a classical education for children. See Silleras-Fernández 2015c, p. 254.

${ }^{35}$ Cárceles 1999, p. 32; Sciacca 1962, pp. 355-357. For a general survey on Castilian Humanism, see also Camillo 1976, pp. 250-251, n. 41 and Camillo 2010 passim.

${ }^{36}$ Jiménez 2008, pp. 103-122. 
Isabel, on the other hand, appears in Ortiz's texts as a sort of precocious pupil, certainly not a wise woman who shows her knowledge. She is transformed by him into a literary character; an early example of a trend that developed more fully in the sixteenth and seventeenth centuries, when she became a character in many theatrical plays and came to appear in books ranging from historical chronicles to Castiglione's The Courtier ${ }^{37}$. She occupies a secondary position in the work, directing the text through her constant questioning of the cardinal, being essentially an active listener. At the beginning of the text Ortiz makes queen Isabel deliver the opening statement and point out the difficulty of her task: Advertí, oh cardenal, de las cosas que están escritas en los libros anteriores, que es mayor el trabajo que sobrellevan los reyes de cuanto creía. This shows why she needs Ortiz's text: so she can train her heir en la vida recta, and formarlo en la costumbre $e$ instruirlo en la doctrina ${ }^{38}$. And some time later we read: los príncipes nada tienen que cumplir con mayor diligencia y firmeza que procurar que los hijos sean buenos y sabios, a task that the historical Isabel took to heart. Then, Ortiz, through Isabel, equates the spiritual wellbeing of the ruler with that of his subjects: La salud spiritual del rey es medicina para el pueblo $y$ la intranquilidad moral y la infelicidad del príncipe producen confusión e incluso la ruina del mismo pueblo ${ }^{39}$. Nonetheless, after this, the queen does not really engage in conversation; rather, she asks questions that provide the sagacious clergyman an opportunity to answer, as a demonstration of his erudition.

Her purpose in engaging with him is to educate [her son] in custom and instruct him in the doctrine. This statement resonates with Thomas Aquinas's conception of virtue not as a quality, but a "habit" (habitus) - a habit perfecting man so he may act well-. This is how virtue was understood in the Latin adaptations of Aristotle's Ethics, and this is how Ortiz comprehended it. As Ortiz states (through the Cardinal and quoting Aristotle), thanks to the acquired habit we do what we need to do when we need to do $i t^{40}$. What we do thanks to a habit remains. And so it continues: Isabel is presented taking in the advice of the Cardinal, without interrupting, so she can develop a proper virtuous ideal that she can apply to herself and to her son.

${ }^{37}$ Castiglione 1903, p. 203. Isabel appears as a literary character in the several theatrical plays from the Golden Age. For example, Lope de Vega's El mejor mozo de España and El niño inocente de la Guardia, Vélez de Guevara's La luna de la sierra, La serrana de la Vera, and La corte del demonio and Tirso de Molina's Antona García, El amor médico, and Doña Beatriz de Silva. See Caba 2008; Ostlund 1997.

${ }^{38}$ Ortiz 1983, p. 42.

${ }^{39}$ Ibidem, pp. 41-42.

${ }^{40}$ Ibidem, p. 189. 
Ortiz has Isabel cite King Solomon, saying, A wise son maketh a glad father. Perhaps, because he appreciates the real Isabel will read this work, he leaves out the second part of the proverb: but a foolish son is the heaviness of his mother (Prov. 10:1). After this, the Cardinal begins to expound his moral doctrine, touching on topics such as the difference between passions and habits, and how the latter helps us to control the former. Then he continues on to a detailed explanation of the virtues, following the Aristotelian principle of the Golden Mean -a preferred middle between two extremes that shows neither extreme or deficiency-. Next, he turns to the vices, and the difference between voluntary and involuntary actions, between the things that can be taught, and those, which are merely natural. At any rate the Cardinal and the Queen agreed: the king's spiritual health is the best medicine for its subjects. Then he moves on to explore more practical matters: like whom to choose as a good teacher for the prince-someone who can also serve as a good counselor (in chapters 20 to 37)-. Through this device and the description he provides, Cardinal Mendoza -or, by implication, Alonso Ortiz himself- appear as ideal candidates for the job. In fact, this may be Ortiz's motive in writing this book $^{41}$. Chapter 44 is particularly interesting because it is the only moment in the book when the queen speaks to give an explanation, and not just to ask, but again her explanation serves to show that she has been a good listener and that now she grasps the importance of being discrete and understands what the golden mean is ${ }^{42}$.

All of this aside, perhaps the most interesting aspect about Ortiz's book is not what he says, but what he implies regarding queenship and Isabel the Catholic, who was at that point a woman at the height of her power, a mother of five children whose education she carefully planned, and a queen ruling in her own right alongside her husband. If we were to read only Ortiz's treatise, and we did not know these facts, or of her involvement in politics and government during the long course of her reign, we might believe that her role in society was very limited. Although she is presented as someone who can follow a complex argument and asks informed questions in Latin, and who

\footnotetext{
${ }^{41}$ Regarding the prince's head teacher, Ortiz, through the cardinal, says, "Es oportuno que para cada disciplina se precise un distinto preceptor, pero todos deben someterse a uno sólo, el cual debe descollar sobre todos por su conducta, por la santidad de sus costumbres y por su misma doctrina, así que los demás le obedezcan en la enseñanza de los jóvenes". At the beginning of the treatise he made the queen say to Cardinal Mendoza: "Pues, tú, cardenal, toma sobre las espaldas esta preocupación que yo he establecido que compartas conmigo y escribas luego algo, en gracia de lo cual los preceptores de nuestro Juan puedan seguir educándolo en el justo camino. Ellos, por cierto, serán los ejecutores de tus preceptos", ibidem, p. 175. It seems clear that Ortiz is putting himself and Mendoza forward as clergymen capable of sharing with the queen the daunting responsibility of educating the next King of Castile and Aragon.
}

${ }^{42}$ Ibidem, book 2, pp. 199-201. 
demonstrates an active intellect, she is nevertheless portrayed as someone who listens, and who requires careful guidance. As the proverb says: Listen to counsel and accept discipline, that you may be wise the rest of your days (Prov. 19:20). And this is what the Queen does in this mirror -a book, that we cannot even be sure if the real Isabel ever read. Here, she is depicted not as a ruling queen, governing Castile and the destiny of her subjects -just as Pulgar had portrayed her, as a mother, and a rather concerned one who is worried about her son and the difficult tasks that lay ahead of him. In other words, she is presented as someone who not only accepts, but also perpetuates the typical role assigned to women in medieval conduct manuals.

This situates Ortiz's book in a long tradition of didactic literature manuals written to guide women to a virtuous and rewarding life, eschewing idleness and aspiring to devotion, in which the most common advice for them was to be obedient, quiet, and to talk only when appropriate ${ }^{43}$. And this is what Isabel does in this speculum principium. However, Ortiz was by no means the only author who wrote for Isabel. For instance, almost thirty years earlier, around 1468, the Augustinian friar, Martín de Córdoba, composed a work in Castilian, the Jardin de nobles doncellas (Garden of Noble Maidens) for the young princess Isabel ${ }^{44}$. Back then she had yet to marry Fernando, and Martín de Córdoba presented himself in the text as an earnest counselor to the princess, whose patronage he was pursuing, while giving her advice regarding the nature of woman, and how she ought to behave. In his mind she should be allowed to inherit the crown, but he proposed two complimentary solutions to the "problem" of female rulership: Isabel should marry and allow her husband to rule, and she should work on perfecting herself as an individual by becoming more masculine. Here, we see an early anticipation of Butler's notion of gender performativity; for Martín de Córdoba Isabel had to behave in a more masculine manner in order to become more perfect ${ }^{45}$.

On the other hand, in literature, which had a more clearly misogynistic bias, women were also characterized in pejorative terms: as breakers of the social order, gossipers, and a general embarrassment to the men around them. Obviously, Ortiz could never characterize Isabel (or women) in such prejudicial

\footnotetext{
${ }^{43}$ For an overview in this type of literature see Silleras-Fernández 2015c, 2013.

${ }^{44}$ See an edition of the text at Córdoba 1953. See also Weissberger 2004, pp. 29-55; SillerasFernández 2015b, pp. 50-52.

${ }^{45}$ Gender, according to Judith Butler, "is in no way a stable identity or locus of agency from which various acts proceed; rather, it is an identity tenuously constituted in time -an identity instituted through a stylized repetition of acts-", Butler 1990, p. 97. Martín de Córdoba's proposal was by no means unique. For example, Juan de Lucena, wrote regarding Isabel: "Oh, heart of a man dressed as a woman, example to all queens, a model for all women". See that and similar examples in Howe 2003, p. 94 and passim.
} 
terms in a book intended for the queen and her son. After all, she was a ruling monarch and, more to the point, she was the one in charge of Juan's education. Therefore, he needed her on his side if he hoped to become one of the prince's instructors and to gain a more important position at the court. In this regard, Ortiz was no different from other moralists, who would shape their literary positions to suit their patrons and readership ${ }^{46}$. Chauvinistic as they may have been, these moralists were far from indifferent to the real influence and the resources that medieval noble women and queens had at their disposal.

Nevertheless, the fact that Isabel was a ruling queen did not discourage Ortiz from portraying her in a passive role in his text, under the strict guidance of the cardinal. This point is rather important, because it touches the core of humanist discourse regarding women -which is that they needed constant and firm male supervision. In this sense, there is not much "modern" in the gender politics of humanist discourse, other than the fact that women were stimulated in these works to acquire a broad education -one that included classical philosophy, theology, and Latin.

In this sense, Ortiz's ideals on education are similar to those of Joan Lluís Vives, who also wanted women to be educated, but who nevertheless advocated for their silence, their passivity, and the strict control of their husbands. In Vives's mind, In a woman, chastity is the equivalent of all virtues ${ }^{47}$. He goes on: Above all, she [woman] should be aware that the principal female virtue is chastity, and it is in itself the equal of all the others in moral worth. If this is present, one need not look for others, and if it is absent, one should disregard the others. Needless to say, Ortiz is not concerned with Prince Juan's chastity, a virtue that was not expected in a prince. In the construction of gender of the time it seemed unimportant for a male. In this sense, we can affirm that Ortiz, like Vives's texts contributed to the creation of a discourse relating to the codification of what was seen by contemporaries as "proper" feminine and masculine behavior, and shows more continuity than disruption from previous models.

\section{CONCLUSIONS}

In sum, however authors like Martín de Córdoba, Pulgar, Ortiz, and Vives may have tried to control discourse and theorize a gendering of power that situated women as secondary and ancillary to men, the reality

${ }^{46}$ See Silleras-Fernandez 2015c, passim.

${ }^{47}$ Vives 2000, p. 85. 
of history worked against them. As it happened, Isabel the Catholic's successor was not her son. After Juan's unexpected death in 1497, Ortiz rushed to compose the Tratado del fallesçimiento del muy ínclito Señor Don Juan, a consolatory treatise aimed to help those who read it to overcome the passing of the prince ${ }^{48}$. At this point, the next in line for the throne was Juan's eldest sister, Isabel, and when she died (and her son also passed on), the succession went to his sister, Juana, who became queen. She was known to posterity by the derogatory name of Juana the Mad, and was held to be mentally imbalanced and unfit to rule. And this run of female succession was not a Castilian anomaly: the sixteenth century was a time in which an unparalleled number of women came to govern in Europe, either in there own right, like Mary Queen of Scots, Mary Tudor, and Elizabeth I in England, or serving in the capacity of lieutenant or regent, like Germana de Foix, Isabel of Portugal, Margaret of Austria, and Mary of Hungary (on behalf of Emperor Carlos V), or Louise de Savoie (1515 and 1525), and Catherine de Médicis (1560-1563) in France ${ }^{49}$. As for Juana I of Castile, due to her inability to rule, the throne ended up going to her son, Carlos who ruled as Carlos I of Spain and Karl V of Germany. When Carlos had his own son and heir, the future Felipe II, his first household (1535-1548) was modeled following that of Prince Juan ${ }^{50}$.

But if Isabel the Catholic did not necessarily read Ortiz's treatise (although she may well have), she -and all of her contemporary queens and female regents- did indeed read books like his. And it was in part thanks to these books that they understood what was expected of them as women; and even if they did not necessarily follow these recommendations, they did use them as outward models in their self-fashioning as queens, women, and rulers. In order to successfully exercise their power (not to mention, their authority), women needed cooperation from their male peers, and in order to obtain this, they needed to present themselves in a non-threatening way, which would allow them both to safeguard their reputation and increase their agency. However, once women, particularly those of the upper classes, had access to the more refined humanist education, they did not necessarily choose to remain silent, as they were encouraged to. This education provided them with more sophisticated intellectual tools -tools they used to better articulate their authority and agency and, in some cases, to rule their own kingdoms-. This

\footnotetext{
${ }^{48}$ There is no agreement regarding to whom this treatise is directed. Bertini, for instance, proposes Cardinal Cisneros, while Sanz argues for Diego de Deza, Prince Juan's teacher and Bishop of Salamanca, Sanz 1993, 167, n. 49; 2000, p. 47.

${ }^{49}$ Earenfight 2015, pp. 103-257; Silleras-Fernández 2015c.

${ }^{50}$ Sánchez-Molero 2013, pp. 78-79.
} 
was a paradoxical and unexpected outcome of humanism discourse regarding women- ${ }^{51}$.

And, indeed, Alonso Ortiz's works -obscure as they may be to literary critics and historians alike- allow us to understand the complex role of writing, Humanism, power, and courtly culture in the fifteenth century. His is a remarkable case of an intellectual at the service of monarchical power, who participated in some of the most stimulating and provocative debates of his time. His persona and his writings show that the substantial and important link between queens, kings, and ideologues is one we cannot neglect as scholars, and it is precisely because of this link that humanist discourse -as distant from reality as it may be- can shed light onto the realities of queenship. In conclusion, the fact that Isabel became such a powerful queen provoked what Barbara Weissberger called anxious masculinity, and this tension shows through in the work of those male authors who had no hope of controlling Isabel in real life, and so endeavored to contol her through the medium of their texts ${ }^{52}$. To me, what is particularly interesting about this case is that it shows the tensions between the framework that male friars, authors, and ideologues constructed for women (even queens), and what these women really did. Texts like Ortiz's Liber de educatione allow us to distinguish between ideas and habits that were prescriptive versus those that were descriptive, and to understand the inevitable tensions between both. Scholars need to be aware of the fact that in political treatises the gaps between theory and practice were immense, and the agency of medival women could be quite considerable.

\section{BIBLIOGRAPHY}

Alcalá, Ángel; Sanz, Jacobo (1999), Vida y muerte del príncipe don Juan. Historia y literatura, Valladolid, Junta de Castilla y León.

Alfonso X (1807), Las siete partidas del Rey Don Alfonso el Sabio, Madrid, Imprenta Real.

Archer, Robert (2005), The Problem of Woman in Late-Medieval Hispanic Literature, Woodbridge, Tamesis.

Azcona, Tarsicio de (1993), Isabel la Católica: estudio crítico de su vida y su reinado, Madrid, Biblioteca de autores cristianos.

\footnotetext{
${ }^{51}$ Silleras-Fernández 2015c, pp. 253-26; 2012. For an analysis of the so called "querelle de femmes" in the Iberian context, and how to understand it, see Archer 2005; Vélez-Sainz 2015. They do not discuss Alonso Ortiz or his works.

${ }^{52}$ Weissberger 2004, pp. XIV-XVI, 1-27.
} 
Azcona, Tarsicio de (2007), Juana de Castilla, mal llamada la Beltraneja: la vida de la hija de Enrique IV de Castilla y su exilio en Portugal (1462-1530), Madrid, La esfera de los libros.

Bianchini, Janna (2012), The Queen's Hand: Power and Authority in the Reign of Berenguela of Castile, Philadelphia, University of Pennsylvania Press.

Butler, Judith (1990), Gender Trouble: Feminism and the Subversion of Identity, New York, Routledge.

Caba, María Yaquelín (2008), Isabel la Católica en la producción teatral española del siglo XVII, Suffolk, Tamesis.

Camillo, Ottavio di (1976), El humanismo castellano del Siglo XV, Valencia, Torres.

Camillo, Ottavio di (2010), Fifteen-Century Spanish Humanism: Thirty-Five Years Later, "La Corónica" 39/1, pp. 19-66.

Cárceles Laborde, Concepción (1993), Humanismo y educación en España (1450-1650), Pamplona, Eunsa.

Castiglione, Baldasarre (1903), The Book of the Courtier, trans. and ed. Leonard Eckstein Opdycke, New York, Charles Scribner's Sons.

Chartier, Roger (1995), Forms and Meanings: Texts, Performances, and Audiences from Codex to Computer, Philadelphia, University of Pennsylvania Press.

Córdoba, Martín de (1953), Jardín de nobles doncellas, Madrid, Colección joyas bibliográficas.

Earenfight, Theresa (2007), Without the Person of the Prince: Kings, Queens and the Idea of Monarchy in Late Medieval Europe, "Gender and History" 19/1, pp. 1-21.

Earenfight, Theresa (2010), The King's Other Body: María of Castile and the Crown of Aragon, Philadelphia, University of Pennsylvania Press.

Earenfight, Theresa (2013), Medieval Queenship, New York, Palgrave Macmillan.

Echevarría, Ana (2002), Catalina de Lancaster, reina regente de Castilla 1372-1418, Madrid, Nerea.

Fanego Pérez, Tomás (2001), Ad Illustrisimos Fernandum et Helisabeth Hispaniarum regem et reginam potentissimos Alfonsi Ortiz doctoris oratio de Alfonso Ortiz: edición crítica de las versiones latina y castellana, "Humanistica Lovaniensia" 50, pp. 91-117.

Fanego Pérez, Tomás (2003), Alfonso Ortiz traductor de Alfonso Ortiz, in Grau i Codina, Ferran (ed.), La Universitat de València i l'Humanisme: Studia Humanitatis i renovació cultural a Europa $i$ al Nou Món, Valencia, Universitat de València, pp. 423-430.

Fernández de Córdova Miralles, Álvaro (2002), La corte de Isabel I: ritos y ceremonias de una reina (1474-1504), Madrid, Dykinson. 
Fernández de Córdova Miralles, Álvaro (2004), Sociedad cortesana y entorno regio, in Ladero Quesada, Miguel Á. (ed.), El mundo social de Isabel la Católica: la sociedad castellana a fines del siglo XV, Madrid, Dykinson, pp. 49-78.

García Castillo, Pablo (2012), Los nuevos tratados de educación: El Liber de educatione de Alonso Ortiz. El humanismo salmantino de los siglos $X V-X V I$, in Cirilo Flórez, Miguel; Hernández Marco, Maximiliano; Albares Albares, Roberto (eds.), La primera escuela de Salamanca (1460-1516), Salamanca, Ediciones de la Universidad de Salamanca, pp. 35-51.

García Oro, José (1971), Cisneros y la reforma del clero en tiempos de los Reyes Católicos, Madrid, Consejo Superior de Investigaciones Científicas.

Gil Fernández, Luis (2004), El Humanismo, in Ribot García, Luis Antonio; Valdeón Baruque, Julio; Maza Zorrilla, Elena (coords.), Isabel la Católica y su época. Actas del congreso internacional, Valladolid, Instituto Universitario de Simancas, vol. II, pp. 1047-1078.

Gómez Redondo, Fernando (2012), Historia de la prosa de los Reyes Católicos: el umbral del Renacimiento, 2 vol., Madrid, Cátedra.

González Iglesias, Juan Antonio (1994), El humanista y los príncipes: Antonio de Nebrija, inventor de las empresas heráldicas de los Reyes Católicos, in Codoñer, Carmen; González Iglesias, Juan Antonio (eds.), Antonio de Nebrija: Edad Media y Renacimiento, Salamanca, Ediciones de la Universidad de Salamanca, pp. 59-76.

González Rolán, Tomás; Baños Baños, José Miguel; Saquero SuárezSomonte, Pilar (2005), El humanismo cristiano en la Corte de los Reyes Católicos: las Consolatorias latinas a la muerte del Príncipe Juan de Diego de Muros, Bernardino López de Carvajal, García de Bovadilla, Diego Ramírez de Villaescusa y Alfonso Ortiz, Madrid, Ediciones Clásicas.

González Ruiz, Ramón (1992), El mundo de la Catedral, in Piedras Vivas. La Catedral de Toledo 1492-1992: Mendoza y Cisneros, dos legados artísticos y culturales, Toledo, Toledo Catedral Primada, pp. 29-54.

Guardiola-Griffiths, Cristina (2011), Legitimizing the Queen: Propaganda and Ideology in the Reign of Isabel I of Castile, Lewisburg, PA, Bucknell University Press.

Hernando Sobrino, María del Rosario (2007), Los toros de Guisando y las glorias ajenas, "Gerión” vol. extra, pp. 341-362.

Howe, Elizabeth Teresa (2003), Zenobia or Penelope? Isabel la Católica as Literary Archetype, in Boruchoff, David A. (ed.), Isabel la Católica, Queen of Castile: Critical Essays, New York, Palgrave, pp. 91-102. 
Jiménez Calvente, Teresa (2008), Maestros de latinidad en la corte de los Reyes Católicos: ¿un ideal de vida o una vida frustrada?, in Salvador Miguel, Nicasio; Moya García, Cristina (eds.), La literatura en la época de los Reyes Católicos, Madrid, Universidad de Navarra Iberoamericana Vervuert, pp.103-126.

Liss, Peggy K. (2004), Isabel the Queen: Life and Times, Philadelphia, University of Pennsylvania Press.

Lop Otín, María José (2002), El cabildo catedralicio de Toledo en el siglo $X V$ : aspectos institucionales y sociológicos, Madrid, Departamento de Historia Medieval, Universidad Complutense de Madrid (doctoral dissertation).

Lop Otín, María José (2005), Un grupo de poder a fines de la Edad Media: los canónigos de la catedral de Toledo, "Anuario de Estudios Medievales" 32/2, pp. 635-669.

Lop Otín, María José (2013), La catedral de Toledo y los escándalos ciudadanos del siglo XV, in Arranz Guzmán, Ana; Rábade Obradó, María del Pilar; Villarroel González, Oscar (eds.), Guerra y paz en la Edad Media, Madrid, Sílex, pp. 181-213.

López Poza, Sagrario (2012), Empresas o divisas de Isabel de Castilla y Fernando de Aragón (los Reyes Católicos), "Janus" 1, pp. 1-38.

Münzer, Jerónimo (1924), Viaje por España y Portugal en los años 1494 y 1495, ed. Julio Puyol, "Boletín de la Real Academia de la Historia" 84, pp. 32-119.

Muñoz Fernández, Angela (1989), Notas para la definición de un modelo sociorreligioso femenino: Isabel I de Castilla, in Muñoz, Ángela (ed.), Las mujeres en el cristianismo medieval: imágenes teóricas y cauces de actuación, Madrid, Asociación Cultural Al- Mudayna, pp. 415-34.

Naim, Moisés (2013), The End of Power: From Boardrooms to Battlefields and Churches to States. Why Being in Charge Isn't What it Used to $B e$, New York, Basic Books.

Nieto Soria, José Manuel (1999), Les miroirs de princes dans l'historiographie espagnole (Couronne de Castile, XIIIe-XVe siècle): tendances de la recherche, in Benedictis, Angela de; Pisapia, Annamaria (eds.), Specula principum, Frankfurt am Main, Vittorio Klostermann, pp. 103-107.

Nieto Soria, José Manuel (2006) Ser reina. Un sujeto de reflexión en el entorno historiográfico de Isabel la Católica, "e-Spania" (online: 09/06/2010), DOI: 10.4000/e-spania.327 [accessed: 13/02/2016].

Nogales Rincón, David (2006), Los espejos de príncipes en Castilla (siglos XIII-XV). Un modelo literario de la realeza bajomedieval, "Medievalismo" 16, pp. 9-40. 
Ortiz, Alonso (1983), Diálogo sobre la educación del príncipe Don Juan, hijo de los Reyes Católicos, ed. Giovanni Maria Bertini, Madrid, Studia humanitatis.

Ostlund, Delys (1997), The Recreation of History in the Fernando and Isabel Plays of Lope de Vega, New York, Peter Lang.

Pelaz Flores, Diana (2013), Queenly Time in the Reign of Juan II of Castile (14061454), in Woodacre, Elena (ed.), Queenship in the Mediterranean: Negotiating the Role of the Queen in the Medieval and Early Modern Eras, New York, Palgrave Macmillan, pp. 169-190.

Pérez, Joseph (2014), Cisneros, el cardenal de España, Madrid, Taurus.

Pulgar, Fernando del (1953), Crónica de los Señores Reyes Católicos Don Fernando y Doña Isabel de Castilla y de Aragón, Madrid, Atlas (Biblioteca de Autores Españoles; 70).

Pulgar, Fernando del (2007), Claros varones de Castilla, ed. Miguel Ángel Pérez Priego, Madrid, Cátedra.

Rábade Obradó, María del Pilar (2007), La educación del príncipe en el siglo $X V$ : del Vergel de los príncipes al Diálogo sobre la educación del príncipe Don Juan, "Res publica: revista de la historia y del presente de los conceptos políticos" 18, pp. 163-178.

Round, Nicholas G. (ed.) (1993), Libro llamado Fedrón. Plato's Phaedo translated by Pero Díaz de Toledo, Madrid, Tamesis.

Rubin, Nancy (1991), Isabella of Castile: The First Renaissance Queen, New York, St. Martin's Press.

Ruiz García, Elisa (2004), Los libros de Isabel la Católica: Arqueología de un patrimonio escrito, Salamanca, Instituto de la historia del libro y de la lectura.

Salvador Miguel, Nicasio (2003), La instrucción infantil de Isabel, infanta de Castilla (1451-1461), in Valdeón Baruque, Julio (ed.), Arte y cultura en la época de Isabel la Católica, Valladolid, Ámbito, pp. 155-177.

Salvador Miguel, Nicasio (2006), Isabel la Católica y el patrocinio de la actividad literaria, Alicante, Biblioteca Virtual Cervantes.

Sánchez-Molero, José Luis Gonzalo (2013), Felipe II: La educación de un felicísimo príncipe (1527-45), Madrid, Polifemo.

Sanz Hermida, Jacobo (1993), Literatura consolatoria en torno a la muerte del príncipe Don Juan, "Studia Historica. Historia Medieval" 11, pp. 157-170.

Sanz Hermida, Jacobo (1997a), Un capítulo oscuro de la historia de la Biblioteca Universitaria de Salamanca: la donación de los libros de Alonso Ortiz, in Beresford, Andrew (ed.), Quien hubiere tal ventura: Medieval Hispanic Studies in Honor of Alan Deyermond, London, University of London, pp. 179-192. 
Sanz Hermida, Jacobo (1997b), Una traducción ignorada de Alonso Ortiz: las meditaciones muy devotas del Bienaventurado San Anselmo, "Livius" 9, 187-203.

Sanz Hermida, Jacobo (2000), Tratado del fallesçimiento el Muy Ínclito Señor Don Juan, Ávila, Institución Gran Duque de Alba.

Sciacca, Michele Federico (1962), El problema de la educación en la historia del pensamiento filosófico occidental, Barcelona, Luis Miracle.

Segura Graiño, Cristina (2007), Influencias de Isabel de Portugal en la educación y formación política de su hija Isabel I de Castilla, in Ribot García, Luis Antonio; Valdeón Baruque, Julio; Maza Zorrilla, Elena (coords.), Isabel la Católica y su época. Actas del congreso internacional, Valladolid, Instituto Universitario de Simancas, vol. I, pp. 319-333.

Shadis, Miriam (2009), Berenguela of Castile (1180-1246) and Political Women in the High Middle Ages, New York, Palgrave Macmillan.

Silleras-Fernández, Núria (2003), Queenship en la Corona de Aragón en la Baja Edad Media: Estudio y propuesta terminological, "La Corónica" 32/1, pp. 119-133.

Silleras-Fernández, Núria (2005-2006), Reginalitat als regnes hispànics medievals: Concepte historiogràfic per a una realitat històrica, "Butlletí de la Reial Acadèmia de Bones Lletres de Barcelona" 50, pp. 121-142.

Silleras-Fernández,Núria (2008), Power, Piety, and Patronage in Late Medieval Queenship: Maria de Luna, New York, Palgrave Macmillan.

Silleras-Fernández, Núria (2012), Paradoxes humanistes: els escrits de Francesc Eiximenis $i$ de Bernat Metge i la seva recepció a la Baixa Edat Mitjana i el Renaixement, "eHumanista. A Journal of Iberian Studies" 1, pp. 154-167.

Silleras-Fernández, Núria (2013), Exceso femenino, control masculino: Isabel la Católica y la literatura didáctica, in Garí, Blanca (ed.), Redes femeninas de promoción espiritual en los reinos peninsulares (siglos XIII-XVI), Barcelona, Universitat de Barcelona - Rome, Viella, pp. 185-202.

Silleras-Fernández, Núria (2015a), Inside Perspectives: Catalina and João III of Portugal and a Speculum for a Queen-to-Be, in Delbrugge, Laura (ed.), Self-Fashioning and Assumptions of Identity in Medieval and Early Modern Iberia, Leiden, Brill, pp. 226-252.

Silleras-Fernández, Núria (2015b), Cada maestrillo tiene su librillo: Personal Reflections on Teaching Gender Through Medieval Iberian Texts, in Gómez, Leila; Horno-Delgado, Asunción; Long, Mary; SillerasFernández, Núria (eds.), Teaching Gender Through Latin American, 
Latino, and Iberian Texts and Cultures, Rotterdam, Sense Publishing, pp. 43-56.

Silleras-Fernández, Núria (2015c), Chariots of Ladies: Francesc Eiximenis and the Court Culture of Medieval and Early Modern Iberia, Ithaca, Cornell University Press.

Suárez Fernández, Luis (1989), Los Reyes Católicos: la conquista del trono, Madrid, Rialp.

Torre, Antonio de la; de la Torre, E. Alsina (1955), Cuentas de Gonzalo de Baeza, tesorero de Isabel la Católica, vol. I., Madrid, Consejo Superior de Investigaciones Científicas.

Val Valdivieso, María Isabel del (2004), Isabel I de Castilla (1451-1504), Madrid, Ediciones del Orto.

Val Valdivieso, María Isabel del (2006), Isabel la Católica y la educación, "Anuario de Estudios Medievales" 19, pp. 558-562.

Vélez-Sainz, Julio (2015), La defensa de la mujer en la literatura hispánica (siglos XV-XVII), Madrid, Cátedra.

Vives, Juan Luis (2000), The Education of a Christian Woman. A SixteenthCentury Manual, ed. and trans. Charles Fantazzi, Chicago, The University of Chicago Press.

Weissberger, Barbara F. (2004), Isabel Rules: Constructing Queenship, Wielding Power, Minneapolis, University of Minnesota Press.

Wolf, Amin (1998), Reigning Queens in Medieval Europe: When, Where, and Why, in Carmi Parsons, John (ed.), Medieval Queenship, New York, St. Martin's Press, pp. 169-88.

Woodacre,Elena (2013), The Queens Regnant of Navarre: Succession, Politics, and Partnership, 1274-1512, New York, Palgrave Macmillan.

Fecha de recepción del artículo: julio 2015

Fecha de aceptación y versión final: febrero 2016 